\title{
Post-ovulatory changes in the water content and inulin space of the rabbit oviduct
}

\author{
B. J. Hodgson* \\ The University of Texas Health Science Center at San Antonio, Department of Obstetrics and \\ Gynecology, 7703 Floyd Curl Drive, San Antonio, Texas 78284, U.S.A.
}

\begin{abstract}
Summary. Measurement of the water content and inulin space of the tissues of the ampulla, ampullary-isthmic junction and proximal isthmus showed that the loss of oedema was related to the position of the ova, whether this was normal (after hCG), delayed (by oestrogen treatment) or accelerated (by progesterone treatment).
\end{abstract}

\section{Introduction}

Most recent investigations into the mechanisms of regulation of oviductal ovum transport have been concerned with the propulsive forces generated by smooth muscle and cilia of the oviduct (see Harper et al., 1976). Black \& Asdell (1959) showed that fluid accumulates in oviducts ligated at the fimbrial end until 3 days after ovulation. They suggested that oedema of the proximal isthmus and the uterotubal junction region could account for the apparent block of fluid flow into the uterus, but were unable to demonstrate oedema histologically and found that ovum transport was unaffected by administration of diuretic agents. Andersen (1928) had previously suggested, on the basis of histological studies, that oedema of the pig uterotubal junction occurs until the 4th day after ovulation. Similar histological studies and conclusions were reported by Edgar \& Asdell (1960) for the ewe. Therefore, although oedema of the oviduct and/or uterotubal junction has been suggested to play a role in the regulation of the timing of ovum transport, there is no direct, quantitative evidence to support this postulate. The present study was designed to determine the water content and extracellular space of rabbit oviducts removed after ovulation or after treatments with oestrogen and progesterone known to alter ovum transport.

\section{Materials and Methods}

After isolation in a constant environment for at least 30 days, 46 sexually mature New Zealand White virgin does (3.5-4 kg) were divided into 5 groups. Animals in Group I were killed at oestrus, determined from the moist and pink appearance of the vulva (ova were not present in the oviducts of this group); those in the other groups each received an ovulation-inducing intravenous injection of $100 \mathrm{i}$.u. hCG (A.P.L., Ayerst, New York) at $0 \mathrm{~h}$. The does in Groups II and III were killed 24 and $72 \mathrm{~h}$ respectively after the hCG injection. The Group IV does were given an intramuscular injection of $2.5 \mathrm{mg}$ progesterone (Proluton: Schering Corp.) at $-48,-24$ and $0 \mathrm{~h}$ and were killed at $+24 \mathrm{~h}$. Group V animals were injected with $250 \mu \mathrm{g}$ oestradiol-17 $\beta$ cyclopentylpropionate (Depo Estradiol: Upjohn Co.) at $0 \mathrm{~h}$ and were killed $72 \mathrm{~h}$ after hCG.

All animals were killed with an overdose of sodium pentobarbital. The oviducts were rapidly excised, trimmed of fat and accessory membranes and the length measured. Segments were taken from the oviduct at positions $20-40,50-60$ and $80-90 \%$ from the fimbrial end and were considered to represent the ampulla, the ampullary-isthmic junction and the proximal isthmus, respectively.

* Deceased. Send reprint requests to Professor M. J. K. Harper, University of Texas Health Science Center, 7703 Floyd Curl Drive, San Antonio, Texas 78284, U.S.A. 
Tissues were dissected in Tyrode's solution (about $10 \mathrm{~min}$ ) at $37^{\circ} \mathrm{C}$ and were cut open longitudinally. To measure water content, tissues were lightly blotted, weighed and dried for $18 \mathrm{~h}$ (to constant weight) at $95^{\circ} \mathrm{C}$ and reweighed.

For inulin space measurements, tissues were placed on hooks and were equilibrated for $30 \mathrm{~min}$ in Tyrode's solution at $37^{\circ} \mathrm{C}$. They were then incubated in Tyrode's solution containing $0.01 \mu \mathrm{Ci}$ $\left[{ }^{14} \mathrm{C}\right]$ carboxyl inulin $/ \mathrm{ml}$ at $37^{\circ} \mathrm{C}$ for $60 \mathrm{~min}$ as described by Goodford (1968) and Paton (1975). The tissues were then rinsed rapidly in Tyrode's solution to remove surface radioactivity, blotted lightly, weighed and digested in tissue solubilizer (Protosol: New England Nuclear). After addition of scintillation fluid radioactivity was counted with a beta scintillation spectrometer. Aliquots of the incubation medium were also counted. Correction for quenching was made by using the channelsratio method. Inulin space was calculated by dividing counts $/ \mathrm{min}$ per $\mathrm{kg}$ tissue wet weight (c.p.m./kg) by counts/min per $\mathrm{ml}$ incubation medium (c.p.m./ml).

\section{Results}

These are shown in Table 1. The water content of oviducts from oestrous animals (Group I) and those in Groups II and V did not differ in any segment, but was significantly reduced in all oviduct segments of progesterone-treated animals and the ampullary-isthmic junction and proximal isthmus of animals killed $72 \mathrm{~h}$ after hCG. The inulin space of the ampulla was less than that of the other two segments. There were no differences between treatment groups for inulin space of the ampulla or ampullaryisthmic junction, but in the isthmic segments the inulin space in Group III animals was higher than that in the other treatment groups.

Table 1. Water content and inulin space of ampulla, ampullary-isthmic junction and isthmus of the oviducts of rabbits killed at oestrus (Group 1), 24 or $72 \mathrm{~h}$ after hCG (Groups II and III), $24 \mathrm{~h}$ after hCG and treated with progesterone (Group IV), and $72 \mathrm{~h}$ after hCG and treated with oestradiol (Group V)

\begin{tabular}{|c|c|c|c|c|c|c|}
\hline \multirow[b]{2}{*}{ Group } & \multicolumn{2}{|c|}{ Ampulla } & \multicolumn{2}{|c|}{ Ampullary-isthmic junction } & \multicolumn{2}{|c|}{ Proximal isthmus } \\
\hline & $\begin{array}{c}\mathrm{H}_{2} \mathrm{O} \\
(\mathrm{ml} / \mathrm{kg})\end{array}$ & $\begin{array}{l}\text { Inulin space } \\
(\mathrm{ml} / \mathrm{kg})\end{array}$ & $\begin{array}{c}\mathrm{H}_{2} \mathrm{O} \\
(\mathrm{ml} / \mathrm{kg})\end{array}$ & $\begin{array}{l}\text { Inulin space } \\
(\mathrm{ml} / \mathrm{kg})\end{array}$ & $\begin{array}{c}\mathrm{H}_{2} \mathrm{O} \\
(\mathrm{ml} / \mathrm{kg})\end{array}$ & $\begin{array}{c}\text { Inulin space } \\
(\mathrm{ml} / \mathrm{kg})\end{array}$ \\
\hline I & $805 \pm 5^{a}(16) \dagger$ & $283 \pm 13^{a}(6)$ & $808 \pm 8^{a b}$ & $348 \pm 21^{a}(6)$ & $790 \pm 7^{\mathrm{ab}}(16)$ & $348 \pm 11^{b}(12)$ \\
\hline II & $797 \pm 3^{a}(28)$ & $288 \pm 15^{a}(6)$ & $809 \pm 3^{a}$ & $306 \pm 16^{a}(6)$ & $795 \pm 3^{\mathrm{a}}$ & $324 \pm 7^{b}(12)$ \\
\hline III & $791 \pm 4^{a}(28)$ & $324 \pm 26^{a}(6)$ & $791 \pm 5^{b c}(14)$ & $377 \pm 21^{a}(6)$ & $781 \pm 5^{b}$ & $382 \pm 8^{a}(12$ \\
\hline IV & $769 \pm 5^{b}(28)$ & $284 \pm 20^{a}(6)$ & $783 \pm 3^{c}$ & $354 \pm 7^{a}(6)$ & $773 \pm 4^{b}$ & $347 \pm 9^{b}(12$ \\
\hline V & $791 \pm 3^{a}(24)$ & $291 \pm 16^{a}(6)$ & $805 \pm 3^{a}$ & $334 \pm 23^{a}(6)$ & $795 \pm 4^{a}$ & $330 \pm 10^{\circ}(12$ \\
\hline
\end{tabular}

$\dagger$ Values are mean \pm s.e.m., number of samples in parentheses. Within each column, values with similar superscripts are not significantly different $(P>0.05$, Student-Neuman-Kuels procedure) (Sokal \& Rohlf, 1969).

\section{Discussion}

The present data provide direct evidence in support of the contention that loss of oedema of the oviduct occurs during ovum transport. At $24 \mathrm{~h}$ after hCG, ova are at the ampullary-isthmic junction or are entering the isthmus, whereas by $72 \mathrm{~h}$ ova are entering or have entered the uterus. At $24 \mathrm{~h}$ after hCG, ova in progesterone-treated animals have entered the uterus whereas by $72 \mathrm{~h}$ ova are still at the ampullary-isthmic junction in oestrogen-treated does (Pauerstein, Anderson, Chatkoff \& Hodgson, 1974). Entry of ova into the uterus is therefore associated with loss of tissue water. Although the present data do not distinguish between water content of smooth muscle and mucosal layers, decreased water content may result in an increase in luminal diameter and decreased resistance to movement of 
fluid and ova through the isthmus or uterotubal junction. In the isthmus at $72 \mathrm{~h}$ after $\mathrm{hCG}$, there is an increase in extracellular space, suggesting that there is a decrease in cell volume, and supports the electron microscope findings of an increase in extracellular space between the muscle cells of the isthmus at $68 \mathrm{~h}$ after hCG treatment (Seki, Rawson \& Hodgson, 1978).

\section{References}

ANDERSEN, D.H. (1928) Comparative anatomy of the tubo-uterine junction histology and physiology in the sow. Am. J. Anat. 42, 255-305.

BlaCK, D.L. \& AsDell, S.A. (1959) Mechanisms controlling entry of ova into rabbit uterus. Am. J. Physiol. 197, 1275-1278.

Edgar, D.G. \& Asdell, S.A. (1960) The valve-like action of the utero-tubal junction of the ewe. $J$. Endocr. 21, 315-321.

GOODFORD, P.J. (1968) The distribution and exchange of electrolytes in intestinal smooth muscle. In Handbook of Physiology; Alimentary Canal, Vol. IV., pp. 17431766. Am. Physiol. Soc., Washington.

Harper, M.J.K., Pauerstein, C.J., Adams, C.E., Coutinho, E.M., Croxatto, H.B. \& Paton, D.M.
(Eds) (1976) Ovum Transport and Fertility Regulation. WHO Symposium, Scriptor, Copenhagen.

Pauerstein, C.J., Anderson, V., Chatkoff, M.L. \& Hodgson, B.J. (1974) Effect of estrogen and progesterone on the time-course of tubal ovum transport in rabbits. Am. J. Obstet. Gynec. 120, 299-308.

PATON, D.M. (1975) Extracellular space measurements. Methods in Pharmacology, Vol. 3, pp. 639-645. Eds E. E. Daniel \& D. M. Paton. Plenum Press, N. Y.

SEKI, K., Rawson, J.M.R. \& HodgSON, B.J. (1978) Post-ovulatory changes in cell contacts and intercellular space of rabbit oviductal smooth muscle. Biol. Reprod. (in press).

SoKal, R.R. \& RohlF, F.J. (1969) Biometry, pp. 239246. W. H. Freeman and Co., San Francisco.

Received 7 December 1977 